\title{
Penggunaan Metode Silabel dalam Meningkatkan Kemampuan Membaca pada Siswa
}

\section{Using Syllable Method in Improving Student's Reading Skill}

\author{
Dinda Permatasari Harahap \\ Fakultas Psikologi, Universitas Medan Area, Indonesia
}

Diterima : 13 April 2020; Disetujui : 14 April 2020; Dipublish : 30 April 2020

*Corresponding author: E-mail: dinda@staff.uma.ac.id

\begin{abstract}
Abstrak
Kemampuan literasi menjadi komponen penting dalam perkembangan anak. Kemampuan literasi merupakan kemampuan individu untuk membaca dan menulis. Tingkat literasi siswa Sekolah Dasar di Indonesia masih tergolong dalam kategori kurang. Hal ini ditunjukkan oleh masih ditemukannya siswa Sekolah Dasar yang belum bisa membaca dan menulis. Tujuan penelitian ini adalah untuk melihat dampak metode silabel dalam meningkatkan kemampuan literasi anak. Metode yang digunakan dalam penelitian ini adalah studi kasus. Partisipan dalam penelitian ini adalah siswa kelas 3 Sekolah Dasar yang berusia 9 tahun. Partisipan mengalami kesulitan belajar terutama kesulitan membaca. Metode yang digunakan untuk meningkatkan kemampuan membaca partisipan yakni metode silabel. Metode silabel merupakan metode yang menggunakan suku kata untuk mengajarkan siswa belajar membaca. Pelaksanaan penelitian dilakukan selama tiga bulan. Peneliti memberikan pelatihan membaca dengan metode silabel yang dilakukan selama 11 sesi. Hasil penelitian menunjukkan bahwa metode silabel dapat meningkatkan kemampuan membaca pastisipan. Partisipan mampu mengenali huruf, melafalkan huruf, menulis huruf, serta membaca kata dengan baik.
\end{abstract}

Kata Kunci: Kesulitan Membaca; Metode Silabel; Literasi.

\begin{abstract}
Literacy is important component in children's development. Literacy is the ability of people to read and write. The level of literacy of elementary students in Indonesia is still classified as lacking. This is incicated by the discovery of elementary students who have not been able to read and write. The purpose of this research was to determine the effect of Silabel Method in literacy skills. The method which is used was single case study. The participant was a 9 years old child in elementary school. The participant has learning difficulty especially in reading difficulty. The method used in this case was Syllable Method. This method is defined as the process of learning to read that begins with the syllables. The intervention was done in three months. The reseacrher gave a reading training using the syllable method which was carried out for 11 sessions. The result showed that the Silabel Method could improve participant's reading skills. The participant begins to recognize letters and letters sound, reads letter names and syllables, and reads simple words.
\end{abstract}

Keywords: Reading Difficulty; Syllables Method; Literacy.

Rekomendasi mensitasi :

Harahap, D.P. (2020). Penggunaan Metode Silabel dalam Meningkatkan Kemampuan Membaca Siswa. Jurnal Penelitian Pendidikan, Psikologi dan Kesehatan (J-P3K), 1 (1): 15-22. 


\section{PENDAHULUAN}

Salah satu kemampuan yang penting dalam proses perkembangan anak adalah kemampuan literasi. Literasi dikenal sebagai kemampuan membaca dan menulis. Namun pengertian literasi tidak hanya sebatas kemampuan membaca dan menulis saja, tetapi juga kemampuan individu menyampaikan hasil pemikiran secara lisan dan tulisan, memahami informasi lisan dan tulisan, dan mengenali serta membunyikan nama huruf dengan baik (Dunst, Trivette, Masiello, Roper, Robyak, 2006). Kemampuan literasi awal yang baik akan meningkatkan kesuksesan anak di sekolah (Senechal \& LeFreve, 2002).

Tingkat kemampuan literasi anak di Indonesia, dapat dilihat berdasarkan hasil asesmen yang dilakukan Indonesian National Assesment Programme (INAP) pada tahun 2016 yang memperoleh hasil bahwa sebanyak 46,83\% siswa Sekolah Dasar di Indonesia memiliki tingkat kemampuan literasi yang berada pada kategori kurang. Selain itu, budaya literasi pada masyarakat Indonesia juga menempati posisi terendah dari 52 negara di Asia Timur. Selain itu Progress in International Reading Literacy Studies (PIRLS) melakukan asesmen pada tahun 2011 yang hasilnya menunjukkan bahwa kemampuan literasi anak di Indonesia masih berada di bawah rata-rata kemampuan literasi anak dunia. Berdasarkan data tersebut, dapat diketahui bahwa komponen literasi masyarakat Indonesia terutama siswa Sekolah Dasar masih perlu mendapatkan perhatian untuk dikembangkan.

Peneliti melakukan pengamatan terhadap beberapa Sekolah Dasar di
Yogyakarta. Berdasarkan hasil pengamatan, masih banyak ditemukan siswa Sekolah Dasar yang memiliki kemampuan literasi yang rendah. Bahkan ada siswa yang sudah berada di kelas 3 Sekolah Dasar, namun masih belum bisa membaca dan menulis. Dampak yang ditimbulkan yakni anak mengalami kesulitan membaca dan menulis yang diasosiasikan dengan rendahnya prestasi sekolah, kurangnya kemampuan literasi saat dewasa, dan meningkatnya masalah perilaku hingga putus sekolah (Burke, 2010).

Menurut Gonzalez, Espinel, dan Rosquete (2002) salah satu faktor yang menyebabkan kesulitan membaca dan menulis pada anak adalah lingkungan sosial yang tidak mendukung seperti tidak adanya stimulasi literasi yang dilakukan lingkungan. Jitendra, dkk (2004) mengemukakan bahwa kemampuan membaca dipengaruhi oleh faktor internal (perkembangan bahasa dan perkembangan kognitif) serta faktor eksternal (stimulasi dari keluarga sejak dini, percakapan dengan anak untuk memperhatikan dan mengarahkan bahasa, pemberian pertanyaan untuk mengembangkan konsep, metode pengajaran, dan jumlah waktu dalam belajar). Oleh karena itu, ada banyak komponen yang penting untuk diperhatikan dalam mengembangkan kemampuan membaca pada anak. Komponen ini tidak hanya dari internal seperti tingkat kognitif anak, tetapi juga eksternal seperti stimulasi dari lingkungan anak yang dalam hal ini keluarga dan institusi pendidikan. 
Peneliti mendampingi salah seorang siswa kelas 3 Sekolah Dasar di Yogyakarta dan melakukan asesmen terhadapnya. Peneliti menemukan permasalahan pada partisipan yakni kesulitan dalam membaca dan menulis. Padahal partisipan sudah berusia 9 tahun dan berada di kelas 3 Sekolah Dasar. Dalam hal ini, peneliti melakukan pendampingan khusus kepada partisipan untuk mengetahui penyebab kesulitan membaca, serta merancang dan melakukan intervensi kepada partisipan. Tujuan pendampingan ini yakni untuk meningkatkan kemampuan membaca pada partisipan.

Adapun pendekatan yang dilakukan kepada partisipan yakni mengajarkan membaca dengan menggunakan metode silabel. Metode silabel dapat digunakan untuk membantu anak yang mengalami keterlambatan atau kesulitan membaca karena dengan silabel, anak dapat mempelajari hubungan antara gabungan huruf yang tertulis dengan bunyinya serta pengenalan kata secara cepat (Wolf, Miller, \& Donnely, 2000).

\section{METODE PENELITIAN}

Metode yang digunakan dalam penelitian ini yakni dengan melakukan asesmen terlebih dahulu terhadap partisipan untuk mengetahui faktor penyebab kesulitan membaca pada partisipan sehingga mampu menegakkan diagnosa serta memberikan intervensi yang tepat bagi partisipan. Prosedur dan pelaksanaan asesmen dapat dilihat pada tabel berikut:

\begin{tabular}{lll}
\multicolumn{2}{l}{ Tabel 1 Prosedur dan Pelasanaan Asesmen } \\
\hline $\begin{array}{l}\text { Aspek } \\
\text { Riwayat }\end{array}$ & Metode & Sasaran \\
$\begin{array}{l}\text { Partisipan } \\
\text { Kemampuancara }\end{array}$ & Orang tua \\
Kognitif & Tes & \\
Kemampuan & Inteligensi & Partisipan \\
membaca & kemampuan & Partisipan \\
& membaca & Orang tua \\
Gambaran & Observasi & Orang tua \\
Emosi & dan & dan \\
& Wawancara & partisipan \\
Interaksi Sosial & Observasi & Orang tua \\
& dan & dan \\
& Wawancara & partisipan \\
Perilaku & Observasi & Orang tua \\
belajar di & dan & dan \\
rumah & Wawancara & partisipan \\
Pola asuh & & Orang tua \\
\hline
\end{tabular}

Berdasarkan hasil observasi, dapat disimpulkan bahwa secara fisik, partisipan memiliki hambatan dalam penglihatan. Partisipan tidak mampu melihat tulisan dalam jarak yang jauh. Partisipan tidak mengalami masalah dalam pendengaran dan gerakan motoriknya. Saat belajar di kelas, partisipan mengalami kesulitan untuk mengikuti pelajaran yang diberikan guru. Hal ini disebabkan karena partisipan belum mampu membaca. Partisipan sangat pendiam ketika di kelas. Partisipan juga cenderung pasif dan tidak aktif bertanya kepada guru ketika ada yang tidak ia mengerti.

Hal ini juga terjadi ketika partisipan menjalani tes psikologi. Suara partisipan sangat pelan sehingga tester harus meminta partisipan berulang kali untuk mengeraskan suaranya. Partisipan raguragu dalam menjawab tes. Selain itu, tester juga harus mengulang-ulang instruksi yang diberikan kepada partisipan.

Berdasarkan hasil wawancara yang dilakukan, didapatkan hasil bahwa partisipan memang mengalami keterlambatan pertumbuhan dan 
perkembangan sejak dilahirkan. Partisipan dilahirkan secara cesar karena lehernya terlilit tali pusar. Selama mengandung, ibu partisipan sangat rajin untuk kontrol ke dokter dan memperhatikan kandungannya. Partisipan mengalami keterlambatan dalam berjalan dan berbicara. Partisipan tidak merangkak saat bayi. Ketika TK, partisipan juga dikeluhkan guru karena terlambat dan sulit mengikuti pembelajaran di kelas. Partisipan belum mampu memegang pinsil dan menuliskan huruf. Hal ini dapat terlihat dalam kutipan wawancara berikut:

"X lahirnya cesar Mbak, dia baru bisa berjalan saat usia dua tahun. Terlambat Mbak. Itu pun adeknya yang duluan jalan, baru dia ikutan belajar jalan. Ngomongnya juga rodo celat. Belum bisa baca tulis Mbak padahal sudah kelas tiga" (Ibu partisipan, wawancara pribadi, Agustus 2018)

Saat berada di Sekolah Dasar, partisipan juga tidak mampu membaca hingga sampai di kelas tiga. Partisipan dibully oleh teman-temannya di sekolah sejak partisipan duduk di kelas satu. Tidak ada teman sekelasnya yang mau bermain dengan partisipan. Partisipan sering mendapat bullyan verbal seperti ejekan dan nonverbal seperti dipukul dan didorong hingga terjatuh. Partisipan cenderung pendiam dan pasif. Ketika marah, partisipan memendamnya dan menangis. Ibu dan ayah partisipan sibuk bekerja sehingga tidak sempat memperhatikan perkembangan akademik partisipan.

Berdasarkan hasil asesmen yang telah dilakukan, dapat disimpulkan bahwa partisipan mengalami gangguan belajar spesifik (specific learning disorder). Adapun kriteria diagnostik dari gangguan ini berdasarkan Diagnostic and Stastical
Manual of Mental Disorders (DSM 5) (American Psychiatric Association, 2013) yakni sebagai berikut:

a) Gangguan belajar spesifik diindikasikan mengalami setidaknya satu dari simptom di bawah ini yang terjadi setidaknya dalam enam bulan terakhir, yang termasuk dalam kesulitan belajarnya yakni sebagai berikut :

Tabel 2 Kriteria Gangguan Belajar Spesifik

Kriteria

perlu usaha keras untuk membaca kata (contoh: membaca sebuah kata dengan salah atau lambat dan ragu-ragu, sering kali menebak kata, kesulitan mengucapkan kata-kata).

Kesulitan memahami arti dari apa yang dibaca (mungkin bisa membaca dengan akurat, tapi tidak mengerti urutan, hubungan, kesimpulan, atau makna yang lebih dalam dari apa yang dibaca).

Kesulitan dengan mengeja (mungkin menambahkan, menghilangkan, atau mengganti huruf vokal dan konsonan).

Kesulitan dengan menulis (membuat beberapa kesalahan dalam tata bahasa atau tanda baca di dalam sebuah kalimat; pengaturan paragraf yang buruk; kurangnya kejelasan dalam ide yang ia tuliskan).

Kesulitan menguasai pemahaman tentang angka atau penghitungan angka (juga bisa tiba-tiba buyar di tengah-tengah penghitungan matematika, langkahlangkah/prosedur penyelesaian soal matematika)

Kesulitan dengan penalaran matematika (memiliki kesulitan yang besar dalam menerapkan fakta, konsep, dan prosedur matematika untuk menyelesaikan masalah-masalah kuantitatif).

Dalam hal ini, intervensi yang akan diberikan kepada partisipan yakni pada 
kesulitan membaca yang dialami partisipan. Feldman (2002) dan Fanu (2006) mengungkapkan bahwa anak-anak yang mengalami kesulitan membaca menunjukkan tanda-tanda kesulitan sebagai berikut :

Tabel 2 Kriteria Gangguan Belajar Spesifik

\begin{tabular}{|c|c|c|}
\hline $\begin{array}{l}\text { Tanda-tanda } \\
\text { Membaca }\end{array}$ & Ada & Tidak \\
\hline $\begin{array}{l}\text { Membaca dengan sangat } \\
\text { lambat dan dengan enggan } \\
\text { terkesan tidak yakin dengan } \\
\text { ucapannya. }\end{array}$ & $\sqrt{ }$ & - \\
\hline $\begin{array}{l}\text { Menyusuri teks pada } \\
\text { halaman buku menggunakan } \\
\text { jari telunjuknya untuk } \\
\text { mengikuti pandangan } \\
\text { matanya. }\end{array}$ & $\sqrt{ }$ & - \\
\hline $\begin{array}{l}\text { Mengabaikan atau } \\
\text { melewatkan suku kata, kata- } \\
\text { kata, frase atau bahkan baris } \\
\text { teks. }\end{array}$ & $\sqrt{ }$ & - \\
\hline $\begin{array}{l}\text { Menambah kata-kata atau } \\
\text { frase yang tidak ada dalam } \\
\text { teks yang dibaca. }\end{array}$ & $\sqrt{ }$ & - \\
\hline $\begin{array}{l}\text { Membolak-balik susunan } \\
\text { huruf atau suku kata dengan } \\
\text { memasukkan huruf-huruf } \\
\text { lain. }\end{array}$ & $\sqrt{ }$ & - \\
\hline $\begin{array}{l}\text { Salah dalam melafalkan } \\
\text { kata-kata yang sedang } \\
\text { dibaca, termasuk kata-kata } \\
\text { yang sudah dikenal. }\end{array}$ & $\sqrt{ }$ & - \\
\hline \begin{tabular}{ll}
\multicolumn{3}{l}{ Mengganti suku kata dengan } \\
kata lain, meskipun kata \\
yang digantikan tidak \\
mempunyai arti & yang \\
penting dalam teks yang \\
dibaca.
\end{tabular} & $\sqrt{ }$ & - \\
\hline $\begin{array}{l}\text { Menyusun kata-kata sendiri } \\
\text { yang tidak mempunyai arti. } \\
\text { Mengabaikan tanda baca. }\end{array}$ & $\sqrt{ }$ & - \\
\hline
\end{tabular}

Berdasarkan tabel tersebut, dapat diketahui bahwa partisipan memenuhi semua kriteria tanda-tanda individu yang memiliki kesulitan membaca. Selanjutnya baseline ditetapkan berdasarkan kemampuan partisipan saat ini dan kemampuan yang masih perlu ditingkatkan pada diri partisipan. Hal ini dapat dijelaskan pada tabel di bawah ini:

\begin{tabular}{ll} 
Tabel 3 Penetapan Baseline \\
\hline $\begin{array}{l}\text { Kemampuan Saat } \\
\text { Ini }\end{array}$ & $\begin{array}{l}\text { Kemampuan yang Belum } \\
\text { Dimiliki }\end{array}$ \\
\hline $\begin{array}{l}\text { Sudah mengenal } \\
\text { huruf abjad. }\end{array}$ & $\begin{array}{l}\text { Belum mampu membaca } \\
\text { kata dengan akhiran huruf } \\
\text { konsonan (b, d, f, h, k, l, m, }\end{array}$ \\
& n, p, r, s, t) \\
$\begin{array}{l}\text { Mampu } \\
\text { menuliskan huruf } \\
\text { abjad. }\end{array}$ & $\begin{array}{l}\text { kelum mata dengan bunyi sengau } \\
\text { (nga, ngi, ngu, nge, ngo, }\end{array}$ \\
$\begin{array}{l}\text { Mampu membaca, nyi, nyu, nye, nyo) } \\
\text { kata } \begin{array}{l}\text { Belum mampu membaca } \\
\text { berakhiran huruf } \\
\text { vokal a, i, u, e, o }\end{array}\end{array}$ & $\begin{array}{l}\text { kata berakhiran vokal } \\
\text { ganda (oi, au, ai) }\end{array}$ \\
\hline
\end{tabular}

Berdasarkan tabel di atas, dapat diketahui bahwa saat ini partisipan sudah mengenal huruf abjad dan mampu menuliskannya. Selain itu partisipan juga mampu membaca kata yang berakhiran huruf vokal a,i,u,e,o. Sedangkan kemampuan partisipan yang masih perlu ditingkatkan yakni kemampuannya membaca kata yang berakhiran huruf konsonan, membaca kata bunyi sengau, akhiran vokal ganda, dan membaca kata sulit. Selanjutnya peneliti merancang dan melakukan intervensi terhadap kemampuan membaca partisipan dengan melakukan konseling terhadap orang tua dan menggunakan metode silabel untuk meningkatkan kemampuan membaca partisipan.

Metode silabel dapat digunakan untuk membantu anak yang mengalami keterlambatan atau kesulitan dalam membaca karena dengan silabel, mereka dapat mempelajari hubungan antara gabungan huruf yang tertulis dengan bunyinya serta pengenalan kata secara cepat (Wolf, Miller \& Donnely, 2000). 
Penelitian silabel ini juga efektif dilakukan oleh Hidayah (2014) terhadap anak kelas II SD di Padang untuk meningkatkan kemampuan membaca permulaan.

Proses pembelajaran membaca permulaan dengan metode silabel diawali dengan pengenalan suku kata, kemudian suku kata dirangkaikan menjadi kata-kata bermakna. Metode silabel didefinisikan sebagai proses pembelajaran membaca yang diawali dengan suku kata, seperti a) ba, bi, bu, be, bo, b) ca, ci, cu, ce, co, c) da, di, du, de, do, d) ka, ki, ku, ke, ko, dan seterusnya. Suku-suku kata tersebut, kemudian dirangkaikan menjadi kata-kata bermakna. (Mulyati, 2011).

Metode ini memungkinkan siswa membaca dengan cara menyajikan suatu kata ke dalam beberapa suku kata berdasarkan pemikiran yang matang, serta situasi yang mendukung kelancaran proses belajar, agar tidak ada bagian-bagiannya yang berkontradiksi, guna mencapai maksud yang ditentukan. Adapun langkahlangkah pembelajaran dengan metode silabel yakni sebagai berikut :
Tabel 4 Langkah-langkan Metode Silabel

\begin{tabular}{|c|c|}
\hline Kegiatan & Penerapan \\
\hline $\begin{array}{lr}\text { Pengenalan } & \text { huruf } \\
\text { alfabet } & \text { A-Z } \\
\text { kemudian } & \text { anak } \\
\text { diajarkan } & \\
\text { menguasai } & \text { huruf- } \\
\text { huruf vokal } & \\
\end{array}$ & $\begin{array}{l}\text { Alfabet: A, b, c, d, e, f, g, h, i, } \\
\text { j, k, l, m, n, o, p, q, r, s, t, u, v, } \\
w, x, y, z \\
\text { vokal : a, i, u, e, o }\end{array}$ \\
\hline $\begin{array}{l}\text { Pengenalan suku } \\
\text { kata }\end{array}$ & ba, bi, bu, be, bo \\
\hline $\begin{array}{l}\text { Latihan membaca } \\
\text { suku kata dari } \\
\text { huruf } \mathrm{p}, \mathrm{b}, \mathrm{t}, \mathrm{d}, \mathrm{m}, \mathrm{n}\end{array}$ & pa, pi, pu, pe, po \\
\hline $\begin{array}{l}\text { Latihan membaca } \\
\text { suku kata dari } \\
\text { huruf } \mathrm{r}, \mathrm{l}, \mathrm{c}, \mathrm{j}, \mathrm{k}, \mathrm{g}\end{array}$ & ra, ri, ru, re, ro \\
\hline $\begin{array}{l}\text { Perangkaian suku- } \\
\text { suku kata menjadi } \\
\text { kata }\end{array}$ & bo-bi, cu-ci, da-da, ka-ki \\
\hline $\begin{array}{l}\text { Perangkaian kata } \\
\text { menjadi kelompok } \\
\text { kata atau kalimat } \\
\text { sederhana }\end{array}$ & ka-ki ku-da \\
\hline $\begin{array}{l}\text { Latihan membaca } \\
\text { kalimat singkat }\end{array}$ & cica cucu papa \\
\hline $\begin{array}{lr}\text { latihan } & \text { membaca } \\
\text { kata } & \text { dengan } \\
\text { akhiran } & \text { huruf } \\
\text { konsonan } & \\
\end{array}$ & $\begin{array}{l}\text { Sebab, tabib, abad, katak } \\
\text { taman, arif }\end{array}$ \\
\hline $\begin{array}{l}\text { Latihan membaca } \\
\text { suku kata dari } \\
\text { huruf ng, ny }\end{array}$ & nga, ngi, ngu, nge, ng \\
\hline $\begin{array}{lr}\text { Latihan } & \text { membaca } \\
\text { kata } & \text { dengan } \\
\text { akhiran } & \text { vokal } \\
\text { ganda } & \\
\end{array}$ & pantai, amboi, harimau \\
\hline $\begin{array}{l}\text { Latihan membaca } \\
\text { kata sulit }\end{array}$ & $\begin{array}{l}\text { Swasembada, swadaya } \\
\text { khasanah, kwitansi, khusus }\end{array}$ \\
\hline
\end{tabular}

Metode silabel yang akan diberikan pada partisipan akan mengacu pada buku Belajar Membaca Tanpa Mengeja (Noviana, 2009). Metode silabel ini dilaksanakan berdasarkan 11 sesi yang ada pada tabel dengan jumlah pertemuan yang disesuaikan dengan keadaan dan kebutuhan partisipan. Waktu yang dibutuhkan untuk satu kali pertemuan yakni selama 30-60 menit. 


\section{HASIL DAN PEMBAHASAN}

Berdasarkan hasil intervensi tutorial membaca yang dilakukan kepada partisipan, didapatkan hasil sebagai berikut:

Tabel 5 Hasil Peningkatan Kemampuan Membaca

\begin{tabular}{|c|c|}
\hline Metode Silabel & Temuan pada Partisipan \\
\hline $\begin{array}{lr}\text { Membaca } & \text { suku } \\
\text { kata } & \text { yang } \\
\text { berakhiran } & \text { huruf } \\
\text { vokal a, i, u, e, o }\end{array}$ & $\begin{array}{lr}\text { Partisipan mampu } & \text { mata yang } \\
\text { membaca kakniran huruf vokal } & \end{array}$ \\
\hline $\begin{array}{lr}\text { Membaca } & \text { suku } \\
\text { kata } & \text { dengan } \\
\text { akhiran } & \text { huruf } \\
\text { konsonan. } & \end{array}$ & 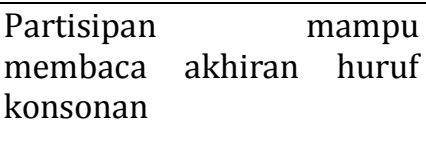 \\
\hline $\begin{array}{l}\text { Membaca } \\
\text { sengau. }\end{array}$ & $\begin{array}{l}\text { Partisipan mampu } \\
\text { membaca ng seperti yang, } \\
\text { meng }\end{array}$ \\
\hline $\begin{array}{l}\text { Membaca rata } \\
\text { dengan akhiran } \\
\text { vokal ganda }\end{array}$ & $\begin{array}{lr}\text { Partisipan mampu } \\
\text { membaca beberapa kata } \\
\text { yang berakhiran huruf } \\
\text { vokal ganda }\end{array}$ \\
\hline Membaca kata sulit & $\begin{array}{l}\text { Partisipan } \\
\text { membaca beberapa kata } \\
\text { sulit }\end{array}$ \\
\hline
\end{tabular}

Partisipan mengalami peningkatan dalam kemampuannya membaca. Partisipan sudah mampu membaca kata berakhiran huruf konsonan, mampu membaca bunyi sengau ng, dan mampu membaca beberapa kata yang berakhiran huruf vokal ganda. Selain itu partisipan juga mampu membaca beberapa kata sulit.

Selain itu, partisipan juga sudah memiliki jadwal belajar membaca rutin yang dilakukan di rumah. Peningkatan ini dapat dilihat dalam grafik berikut ini:

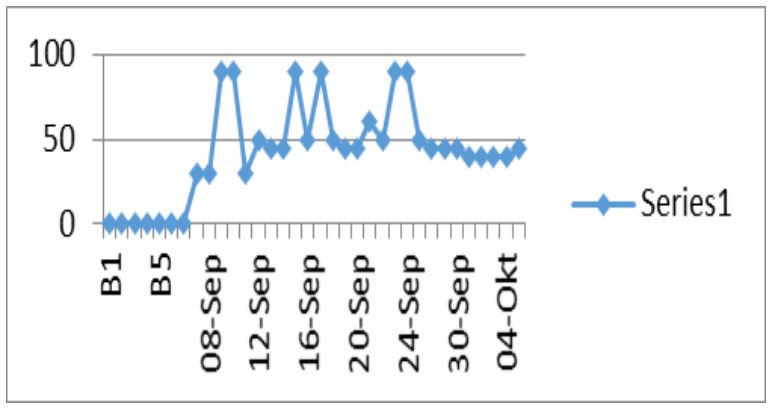

Gambar 1. Grafik Peningkatan Durasi Belajar

Berdasarkan hasil grafik di atas, dapat dilihat bahwa ibu partisipan sudah konsisten dalam mendampingi partisipan dalam belajar di rumah. Selain itu, selama dua kali dalam satu minggu, partisipan dibantu oleh guru les yang datang ke rumah. Rata-rata durasi yang dihabiskan partisipan untuk belajar membaca yakni selama 52 menit per hari.

\section{SIMPULAN}

Berdasarkan intervensi yang dilakukan terhadap partisipan, diperoleh hasil bahwa partisipan mengalami kemajuan dalam kemampuan membacanya. Partisipan sudah mampu membaca beberapa akhiran huruf konsonan, membaca kata sulit yang menggunakan huruf ng misalnya meng dan yang serta beberapa kata sulit lainnya seperti Minggu.

Peningkatan

kemampuan membaca partisipan juga disebabkan oleh dukungan yang dilakukan oleh orang tua dan guru partisipan. Selama dilakukan pendampingan, orang tua dan guru sangat kooperatif sehingga memudahkan peneliti dalam melakukan intervensi kepada partisipan. Ibu partisipan mau melakukan pendampingan terhadap partisipan ketika di rumah, memberikan pelajaran 
tambahan dengan guru, dan menyadari bahwa penting untuk memperhatikan tumbuh dan kembang anak.

Selain itu, guru dan sekolah juga mendukung pelaksanaan intervensi dengan memberikan informasi perkembangan kemampuan membaca partisipan selama di sekolah. Hal ini berarti tidak hanya faktor internal atau diri partisipan saja yang berperan dalam keberhasilan partisipan, tetapi juga faktor eksternal yang dalam hal ini adalah guru dan orang tua partisipan.

\section{UCAPAN TERIMAKASIH}

Terima kasih kepada partisipan dan keluarga partisipan yang sudah bersedia mengikuti proses pendampingan dari awal hingga akhir. Terima kasih juga kepada pihak sekolah yakni SD Negeri 1 Lempuyangan Yogyakarta, yang sudah mengizinkan peneliti melakukan penelitian dan memudahkan segala proses pelaksanaan penelitian.

\section{DAFTAR PUSTAKA}

American Psychiatric Association. 2013. Diagnostic and statistical manual of mental disorder fifth edition. Library of Congress Cataloging in Publication Data: Washington DC

Burke, C. (2010). Mindfulness-Based Approaches with Children and Adolescents: A Preliminary Review of Current Research in an Emergent Field. Journal of Child and Family Studies, 19, 133-144

Dunst, C.J., Trivette, C.M., Masiello, T., Roper, N., \& Robyak, A. 2006. Framework for developing evidence-based early literacy learning practices. Center for Early Literacy Learning Papers 1(1), 1-12.

Fanu, J. 2006. Deteksi Dini Masalah-masalah Psikologi Anak. Yogyakarta:Think.
Feldman, S. 2002. Human Relations. London:Sage Publications

Gonzalez, M., Espinel, A.I.G., \& Rosquete, R.G. 2002. Remedial interventions for children with reading disabilities: speech perception an effective component in phonological training?. Journal of Learning Disability. 35, 334-342.

Hidayah, R. 2014. Kemampuan baca-tulis siswa. Jurnal Ilmu Bahasa dan Sastra Volume 4, Nomor 1, , Y. 2011

Jitendra, A.K., Edward, L.L., Starosta, K., Sacks, G., Jacobson, L.A. \& Choutka, C.M. 2004. Early reading instruction for children with reading difficulties: meeting the needs of diverse learner. Journal of Learning Disabilities. 37, 421-439.

Noviana, I. 2009. Belajar Membaca Tanpa Mengeja. Pustaka Widyatama:Yogyakarta.

Senechal, M \& LeFreve, J. 2002. Parental involvement in the development of child's reading skill: A five Year Longitudinal Study. Child development, March/April 2002, Volume 73, Number 2, page 445-460

Wolf,M., Miller,l., \& Donnely,K. 2000. Retrieval, automaticity, vocabulary elaboration, orthography, (RAVE-0): a comprehensive, fluency-based reading intervention program. Journal of Learning Disability, July-August; 33(4); 375-386 